\title{
Impact of Attachment Styles on Relationship Satisfaction: Mediating Role of Phubbing Behavior
}

\author{
Marryam Shams ${ }^{1 *}$ \\ Umer Iftikhar ${ }^{2}$ \\ Ahtesham Ali Raja
}

\begin{abstract}
Being a technology driven and triggered world, it is extremely important for the individuals to remain virtually connected. But sometimes such virtual connections lead the individuals towards phubbing because of which relational satisfaction among the individuals has been lost. The purpose of our study is to analyze the impact of the individual attachment styles on the relationship satisfaction by the mediating role of phubbing behavior. In light of Bowlby attachments styles our study conceptualizes that secured individuals are contended with their surrounding's hence phub less, and remain contended in their relationships. Whereas the insecurely attached individuals are the ones who phubbed more which ultimately leads them towards less relationship satisfaction. The present study is the first to conceptualize such framework.
\end{abstract}

Keywords: secure attachment, insecure attachment, phubbing behavior, relationship satisfaction

1. MS Scholar, Air University School of Management, Air University Islamabad. email: marryamshams@gmail.com

2. Assistant Professor, Leadership and Management Studies Department, National Defence University Islamabad, email: iftikhar@ndu.edu.pk

3. M.Phil Scholar, Leadership and Management Studies Department, National Defence University Islamabad.email:a_aliraja@yahoo.com 
IBT Journal of Business Studies Volume 15(1), 2019

\section{INTRODUCTION}

Smartphones have lately overtaken laptops and computers as the most communal device that is accessed by the people in order to use the cyberspace (Buckle, 2016). These devices facilitate people to interconnect with everybody everywhere, smoothing shared communications with individuals who are very close by, or very far seems to be on the other side of the world. Though, in spite of their noticeable benefits in getting people together, mobile phones may at times pull people away from each other (Turkle S. , 2012). In actual, persons habitually snubthose with which they have substantial connection in order to use their phone either. This habitual phenomenon of people, is termed as phubbing, appears to have developed perspective in normal intercourse (Chotpitayasunondh \& Douglas, 2016). One latest research stated that $90 \%$ of individuals used their cellphones throughout their utmost latest societalaction, and also professed that $86 \%$ of the others immersed in the social communication did the same (Rainie, Lee; Zickuhr, Kathryn, 2015).

Phubbing is not a novel conception as with the progression of technology and use of smartphones devices and social networking sites (SNS) has amplified resultantly this phenomenon ascendsin a different way. Some recent studies have examined the predictors of phubbing behavior. Among all, utmost significant factor seems to be cell phone obsession (Chotpitayasunondh \& Douglas, 2016). Other predictors such as Internet addiction (T'ng, Ho, \& Low, 2018), fear of missing out (Franchina, Abeele, van Rooij , Coco, \& Marez, 2018), self-esteem, satisfaction and loneliness (Błachnio \& Przepiorka, 2018) and trait boredom (Al-Saggaf, MacCulloch, \& Wiener, 2018) have been found to predict phubbing behavior. Also, Chotpitayasunondh (2016) have established that phubbing conduct itself forecasts the sum to which individuals are phubbed, so that being a phubber can result in an awful, self-fortifying cycle of phubbing that influences the actions and hence become a norm of the society.Study on the aftermath of phubbing proposes that it may generated estructive, offended responses such that persons recognize their communication to be of inferior value (Rainie, Lee; Zickuhr, Kathryn, 2015), are little contented with their communications (Abeele, Mariek M.P. Vanden ; Antheunis, Marjolijn L. ; Schouten, Alexander P., 2016), feel so close to their communication companion when a mobile is existent (Misra, Shalini ; Cheng, Lulu; Genevie, Jamie ; Yuan, Miao, 2014), depression (Roberts \& David, 2016), and less worker commitment when their supervisor portrays phubbing behavior (Roberts, James A.; David, Meredith E., 2017).

Thus, scholars have learned valued evidence about several aspects that may become a basisof this phubbing behavior, and what other impacts of phubbing might be. Though, study on this area is still in its beginning and there is much still to determine. Even though phubbing has turned out to be an emerging part of concern in latest years, investigation on the social concerns of phubbing is inadequate. Preceding research has used big five personality trait model as a predictor of the phubbing behavior (T'ng, Ho, \& Low, 2018) but although no such research has been conducted which have used attachment styles (T'ng, Ho, \& Low, 2018) in the perspective of phubbing. Although these styles had previously been used in the perspective of social media addiction (Demircioğlu \& Köse, 2018). T'ng, Ho, \& Low (2018) also recommended to use these styles as predictors of phubbing behaviour. But no such study exists that depicts these styles in the context of phubbing behavior. In the present research, we intend to complete another part of the conundrum by the help of these research questions; what are those attachment styles that depict phubbing behavior? Whatmediating impact does phubbing behavior have on attachment styles and relationship satisfaction? To answer these queries, the existingstudystructures phubbing as a mediating variable that headed for the relationship satisfaction. 
IBT Journal of Business Studies Volume 15(1), 2019

\section{Attachment Theory, Social Comparison Hypothesis \& Displacement Hypothesis}

\section{Attachment Theory}

As per Bowlby's description, attachment is defined as the affiliation of a baby developed with the care giver or the longing of the baby for the formation of the affiliation with the caretaker (Bowlby, 1988). Professed gratification from the attachment symbol's receptiveness to the wants and calls of the infantforms "model of others" aspect of attachment, apparent worth of self in the eyes of others establishes “model of self”'facet of attachment. Via these two autonomous extents, Bartholomew and Horowitz in year 1991 designed the four classifications model which identified secure, preoccupied, dismissive, and fearful attachment styles. According to these scholars, both the image of self and others are affirmative in case of secure attachment. Securely attached individuals are generally contented with closeness and independence. Preoccupied, dismissive, and fearful styles are entitled as an insecure attachment styles. Because in preoccupied attachment, one's thinking about self is undesirable however perceptions about others is affirmative. Individuals having preoccupied style are usually anxious with associations and despite the fact that they are uncertain about their own worth; they have an intense yearning to be acknowledged and accepted by others. In dismissive style of attachment, model of one's self is affirmative while insights about other people are deleterious. Individuals having such style mostly escape closeness. Lastly, in fearful style, both extents of attachment are undesirable. Personalities with fearful attachment are usually dreadful of forming relationship and such individuals are also delineated as communally avoidant (Bartholomew, K., \& Horowitz, L. M. , 1991).

\section{Social Comparison Hypothesis [SCH]}

The SCH proposes that youngsters with great intensities of communal apprehension may involve in more progressive attachment eminence if they use smart devices with networks to a larger degree than those individuals who also have public nervousness but do avoid smart devices when they are with their fellows (Cambell, 2006). It is constant with thinking that homebodies and socially apprehensive youths, having trouble forming relationships, are more expected to use the digital worldfor the reason that they replace online acquaintances for an unwanted disconnected communal relationship (Valkenburg P. S., 2005). In actual fact, various socially apprehensive personalities stated that recompensing for their public concern is a motive behind they use smart devices with associates, predominantly online networking (Peter, 2006). Social networks that emerge over the digital world comprise primarily of text messages, and consequently, if youngsters use web bases cameras, any photographic info distinctive of outdate done-to-onecommunications is obscured in online dialogs. Likewise, using smart devices with associates may direct concentration and eye stare away from the communally apprehensive adolescent and towards the smart devices display. Particularly, socially nervous youngsters frequently elude eye stare (Albano, 1995), scholars have recommended that interconnecting with inadequate eye stares or cinematic prompts may form a more contented social state for publically apprehensive adolescents in contrast to outdatedone-toone communications (Tyler, T. R., 2002), inclining to a SCH. To put it another way, individuals with greatdegree of social fretfulness may experience more affirmative attachment attribute if they engaged insmart phone devices when they are with their friends to a superior level than their partners who also have high public apprehension but do not use smartphones with associates.

\section{Displacement Hypothesis}

This theory advocates that time expended by an individual on media, may dislodge (or diminish) significant communications with one's associate. For instance, mot paying full attention while 
having the discussions together because of smart phones linked disruptions possibly will lead to poorer degrees of contentment with one's significant other (Coyne S. M.-W., 2014). In other words, this hypothesis theorizes a proportioned, zero-sum connection. It declares that amount of time spent on television is interrelated to the amount of hours expended on several other events. The more hours spent on viewing television, the a lesser amount of time a person will dedicate to other doings; on the contrary the less time expended on seeing television, the more time an individual will allocate to other events (Mutz, 1993).

\section{LITERATURE REVIEW}

\section{Attachment Styles and Phubbing Behavior}

In accordance with the propositions of the attachment theory that we had discussed earlier, low degrees of social fitness is present among the individuals having insecure attachment styles as they usually avoids offline communications with their associates and try to avoid them whenever possible (Wei, 2005). Insecure individuals usually hesitant and avoids such direct one-to-one communications, one of the way of avoiding such interactions is the use of the internet (cell phones) in the presence of their associates, as this obsession may offer a comparatively more safest way for those who avoid sustaining and forming such social interactions. Furthermore, SCH also supported that digital world dependenc ecan be a recompensing process for persons having inadequate or few means for developing offline communal associations, that's why the individuals having more disposition headed fordigital world are likely to snub others while having a direct conversation, as they are more inclined and feeldesire in escaping direct conversations, and get involved with their smart devices (Valkenburg P. M., 2007). Karadag, et al., (2015) also revealed that Internet dependence is a substantial backer to phubbing behavior, and that means insecure individuals tend to avoid others in order to snub them.

Though a lot of research work concentrated on the impact of attachment styles on different variables, the scholarly work which studied the relationsamongst adult styles of attachment and phubbing behavior doesn't exists. These dimensions of attachment have not been connected directly with the phubbing behavior even though they have been associated with many predictors of the phubbing behavior. One of such study, in which adults with secure attachment indicated lesser degrees of challenging smartphone use in comparison to insecure attachment (Lei, L., \& Wu, Y, 2007). One more research specified that addiction towards internet and avoidant styles is directly as well as positively associated with each other (Shin, 2011). Moreover, apprehensive and avoidant styles constructed as the predictor of social media obsession and that obsession will ultimately leads the individuals to snub others while having a direct conversation (Blackwell, D., Leaman, C., Tramposch, R., Osborne, C., \& Liss, M., 2017). Jenkinset al. (2013) reported that persons with disbanding and dreadful connection described more repeated social networking site user than those with securely attached person. In addition, secure style of attachment was originatedas a defensive factor and insecure attachment styles were constituted as threat aspects not only for social media but also for the digital world (Monacis, 2017), as it lead towards phone snubbing. In light of the attachment styles model and SCH theory, the discussions which we had made above; we are concluding our first argument with a proposition that:

Proposition-1: $\quad$ Secure attachment style is negatively whereas insecure attachment styles (fearful, dismissive, and avoidant) are directly linked with phubbing behavior. 


\section{Phubbing Behavior and Relationship Satisfaction}

Relationship satisfaction has been described as a personal assessment of an individual's contentment, pleasure, and preference acquired from his/her association (Hawkins, 1968). Individuals that feel contentment with their associations supposed to have the greater amount of reliance and they are categorically inclined towards their significant others for the contentment of their basic wants (Rusbult, C. E., \& Buunk, B. P., 1993). Conversely, persons who are discontented with their associations are expected to recompense for emotive and communal sustenance through online and digital world. Valenzuela et al. (2014) recommended that amount of time allocatedto social media and other sites were in relation with the person's lower level of contentment with an association whereas those individuals who possessed strong contentment from their relationship were usually avoid digital world and preferred more direct communication.

A steady and vigorous connection is observed by numerous individuals as the foundation of contended people and balanced relations (Coyne S. M., 2011). However, with the consistently expanding occurrence and utilization of personal digital assistants, the limits that different concerns and partnera ssociations have moved toward becoming progressively "obscured" (Leggett, 2014). For a connection to be equally fulfilling, every individual should be present for the significant other (Siegel, D. J., 2010). It isn't sufficient to be only in one another's company; however there must be an association between them. Leggett (2014) characterize presence as "... a procedure whereby we stay open and concentrated on the other without any distractions both internally as well as externally".

In the book, Alone Together (Turkle S. , 2011), Turkle claimsthat cyberspace usage is isolating individuals from each other. Basically, individuals might be physically together, however not completely present (both physically and mentally) for one another. This snubbing phenomenon of individuals through smart phone can be explained in relation to the displacement theory which (Coyne S. M.-W., 2014) clarify the deadly impacts of phubbing on relationship fulfillment. This hypothesis recommends that amount of time that individual spent on media, for example, phones, may dislodge (or lessen) important associations with their friends or families. For instance, not being completely present amid discussions or shared time together as a result of smart devices related diversions could prompt lesser proportions of fulfillment with their associations. Hence we can propose from the discussion above that:

Proposition-2 Individuals with insecure attachment styles will phub more resultantly having low in relationship satisfaction whereas securely attached individuals will phub less and have high relationship satisfaction.

\section{Conceptual Framework}

Here in our model we conceptualize attachment styles as independent variables, relationship satisfaction is dependent variable, and phubbing behavior is a mediating variable. 


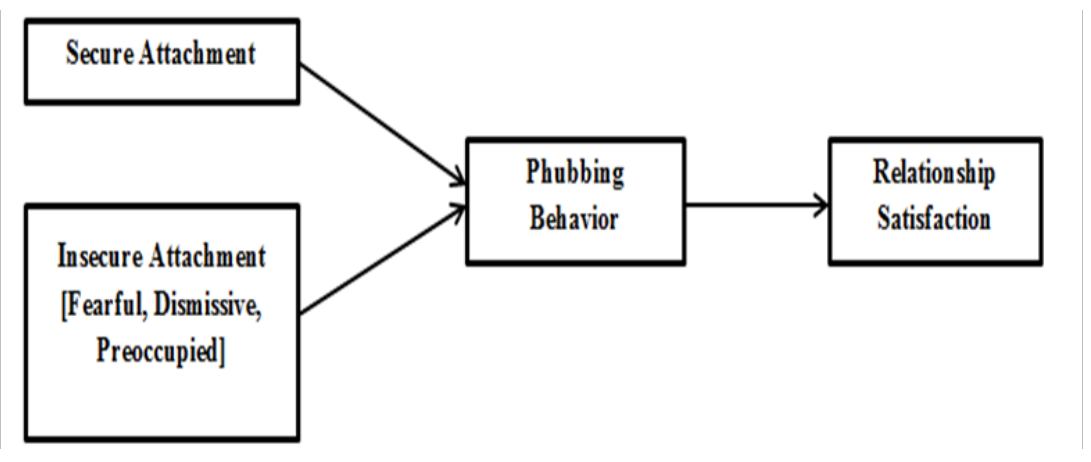

\section{Research Objectives}

The following are the research objectivesbased upon which we had developed our propositions;

RO1- To investigate the impact of secure attachment style upon phubbing behavior.

RO2- To investigate the impact of insecure attachment styles upon phubbing behavior.

RO3- To investigate the mediating role of phubbing behavior in relation to secure attachment style and relationship satisfaction.

RO4- To investigate the mediating role of phubbing behavior in relation to insecure attachment styles and relationship satisfaction.

Research Questions

To explore and analyze the importance of attachment styles following research questions have been asked;

RQ1- What are those attachment styles that depict phubbing behavior?

RQ2- What mediating impact does phubbing behavior has on attachment styles and relationship satisfaction?

\section{Study Contributions}

The existing research makes quite a few significant conceptual contributions to the current body of knowledge. First, in this study we conceptualize a framework in which relationship satisfaction has been predicted by the attachment styles of an adult and the mediating role of phubbing behavior has also been proposed. The major topic of concern is the phubbing behavior as in the past it was linked with personality traits (T'ng, Ho, \& Low, 2018), fear of missing out (Franchina, Abeele, van Rooij , Coco, \& Marez, 2018), and satisfaction and self-esteem (Błachnio \& Przepiorka, 2018) but here in this study we have added in the existing literature by conceptualizing behavior of phubbing in the context of attachment styles of adult.

Our study is the first to conceptualize a connection between attachment styles, phubbing behavior, and relationship satisfaction. Regardless of the growing trend of snubbing others in the presence of smart phone, a very little research has concentrated on the phubbing aspect of individuals having different styles of attachment. Even though preceding research has established that the foremostaim of social media is to associate communally (Van Meter, 2015). The problem remains, though, not withs tanding of these affiliations, people today needs relationship contentment. Currentlywe live in the most associated world to date. Be that as it may, the accessibility of innovation and technology, whose expressed intention is to enable us to associate, we might be less associated than any time in recent years. The present study proposes a conceivable response to this problem. Our research conceptualizes and provides a new insight by establishing a relationship that not only technology through which we are disconnected but one of the major reason behind our relationship satisfaction 
is the individuals attachment styles which determine which individual will phub more.

\section{CONCLUSION}

We have argued that the attachment styles helps in determining the phubbing behavior of an individual. People with secured attachment style are less inclined towards their cell phones hence they phub less. And those having insecure attachment styles will phub more. In association with the social compensation hypothesis we explained our argument that individuals who feels less contended towards social environment will be more inclined towards online communication and networking; hence they phub more. While forming an argument in the support of displacement hypothesis we believe that offline communications and relationships among individuals have been dislodged by the smart phone devices, resultantly negatively impacting the relationship satisfaction among the people.

\section{REFERENCES}

Abeele, Mariek M.P. Vanden ; Antheunis, Marjolijn L. ; Schouten, Alexander P. (2016). The effect of mobile messaging during a conversation on impression formation and interaction quality. Computers in Human Behavior, 62, 562-569. doi:10.1016/j.chb.2016.04.005

Albano, A. (1995). Treatment of social anxiety in adolescents. Cognitive and Behavioral Practice, 2, 271-298.

Al-Saggaf, Y., MacCulloch, R., \& Wiener, K. (2018). Trait Boredom Is a Predictor of Phubbing Frequency. Journal of Technology in Behavioral Science , 1-8. doi:10.1007/s41347-018-0080-4

Bartholomew, K., \& Horowitz, L. M. (1991). Attachment styles among young adults: A test of a four-category model. Journal of Personality and Social Psychology, 61(2), 226-244. doi:10.1037/0022-3514.61.2.226.

Błachnio, A., \& Przepiorka, A. (2018). Be Aware! If You Start Using Facebook Problematically You Will Feel Lonely: Phubbing, Loneliness, Self-esteem, and Facebook Intrusion. A CrossSectional Study. Social Science Computer Review , 1-9.

Blackwell, D., Leaman, C., Tramposch, R., Osborne, C., \& Liss, M. (2017). Extraversion, neuroticism, attachment style and fear of missing out as predictors of social media use and addiction. Personality and Individual Differences, 69-72.

Bowlby, J. (1988). A secure base: Parent-child attachment and healthy human development. New York: New York: Basic Books.

Buckle, C. (2016, September 14). Mobiles seen as Most Important Device. Retrieved from blog. globalwebindex: https://blog.globalwebindex.com/chart-of-the-day/mobiles-seen-as-mostimportant-device/

Cambell, A. J. (2006). Internet use by the socially fearful: Addiction or therapy? CyberPsychology \& Behavior, 9, 69-81.

Chotpitayasunondh, V., \& Douglas, K. M. (2016). How "phubbing” becomes the norm: The antecedents and consequences of snubbing via smartphone. Computers in Human Behavior, 63, 9-18. doi:10.1016/j.chb.2016.05.018

Coyne, S. M. (2011). I luv u :): a descriptive study of the media use of individuals in romantic relationships. Family Relations, 150-162.

Coyne, S. M.-W. (2014). Media time = family time: positive media use in families with adolescents. Journal of Adolescent Research, 29(5), 663-688.

Demircioğlu, Z. I., \& Köse, A. G. (2018). Effects of attachment styles, dark triad, rejection sensitivity, and relationship satisfaction on social media addiction: A mediated mode. Current 
IBT Journal of Business Studies Volume 15(1), 2019

Psychology, 1-15.

Franchina, V., Abeele, M. V., van Rooij , A. J., Coco, G. L., \& Marez, L. D. (2018). Fear of Missing Out as a Predictor of Problematic Social Media Use and Phubbing Behavior among Flemish Adolescents. International Journal of Environmental Research and Public Heath, 15, 1-18. doi:10.3390/ijerph15102319

Hawkins, J. L. (1968). Associations between companionship, hostility, andmaritalsatisfaction. Journal of Marriage and the Family, 30(4), 647-650.

Jenkins-Guarnieri, M. A., Wright, S. L., \& Johnson, B. D. (2013). The interrelationships among attachment style, personality traits, interpersonal competency, and Facebook use . Psychology of Popular Media Culture, 2(2), 117-131.

KARADAĞ, E., TOSUNTAŞ, Ş., ERZEN, E., DURU, P., BOSTAN, N., ŞAHIN, B. M., BABADAĞ, B. (2015). Determinants of phubbing, which is the sum of many virtual addictions: A structural equation model. Journal of Behavioral Addictions, 4(2), 60-74. doi:10.1556/2006.4.2015.005

Leggett, C. \&. (2014). The impact of technology use on couple relationships: a neuropsychology perspective. International Journal of Neuropsychotherapy, 44-57.

Lei, L., \& Wu, Y. (2007). Adolescents' paternal attachment and internet use. Cyberpsychology \& Behavior, 10(5), 633-639. doi:10.1089/cpb.2007.9976

Merchant, B. (2017). The One Device: The Secret History of the iPhone. New York: Little, Brown and Company.

Misra, Shalini ; Cheng, Lulu ; Genevie, Jamie ; Yuan, Miao. (2014). The iPhone Effect. Environment and Behavior, 48(2), 275-298. doi:10.1177/0013916514539755

Monacis, L. d. (2017). Social networking addiction, attachment style, and validation of the Italian version of the Bergen social media addiction scale. Journal of Behavioral Addictions, 1-9.

Mutz, D. C. (1993). Reconsidering the Displacement Hypothesis. Communication Research, 20(1), 51-75. doi:10.1177/009365093020001003

Pathak, S. (2013, October 7). MCCANN MELBOURNE MADE UP A WORD TO SELL A PRINT DICTIONARY. Retrieved from Adage.com: https://adage.com/article/news/mccannmelbourne-made-a-word-sell-a-dictionary/244595/

Peter, J. V. (2006). Characteristics and motives of adolescents talking with strangers on the Interent. CyberPsychology \& Behavior, 526-530.

Rainie, Lee; Zickuhr, Kathryn. (2015). Americans' views on mobile etiquette. Retrieved from Pew Research Center: http://www. pewinternet.org/2015/08/26/americans-views-on-mobileetiquette/.

Roberts, J. A., \& David, M. E. (2016). My life has become a major distraction from my cell phone: Partner phubbing and relationship satisfaction among romantic partners. Computers in Human Behavior, 54, 134-141.

Roberts, James A.; David, Meredith E. (2017). Put down your phone and listen to me: How boss phubbing undermines the psychological conditions necessary for employee engagement. Computers in Human Behavior.

Rusbult, C. E., \& Buunk, B. P. (1993). Commitment processes in close relationships: An interdependence analysis. Journal of Social and Personal Relationships, 10(2), 175-204. doi: $10.1177 / 026540759301000202$

Shin, S. N. (2011). Comparison of problematic internet and alcohol use and attachment styles among industrial workers in Korea. Cyberpsychology, Behavior, and Social Networking, 14(11), 665672. doi:10.1089/cyber.2010. 047

Siegel, D. J. (2010). The mindful therapist: A clinician's guide to mindsight and neural integration. New York: New York, NY: Norton.

T’ng, S. T., Ho, K. H., \& Low, S. K. (2018, July 30). Are you “phubbing” me? The Determinants 
of Phubbing Behavior and Assessment of Measurement Invariance across Sex Differences. International and Multidisciplinary Journal of Social Sciences, 7(2), 159-190. doi:10.17583/ rimcis. 2018.3318

Turkle, S. (2011). Alone together : why we expect more from technology and less from each other. New York: New York :Basic Books.

Turkle, S. (2012). Alone Together: Why We Expect More from Technology and Less from Each Other. New York: NY: Basic Books.

Tyler, T. R. (2002). Is the Internet changing social life? It seems that more things change, the more they stay the same. Journal of Social Issues, 58, 195-205.

Valenzuela, S., Halpern, D., \& Katz, J. E. (2014). Social network sites, marriage well-being and divorce: Survey and state-level evidence from the United States. Computers in Human Behavior, 36, 94-101. doi:10.1016/j.chb.2014.03.034

Valkenburg, P. M. (2007). Who visits online dating sites? Exploring some characteristics of online daters. Cyberpsychology \& Behavior, 10(6), 849-852. doi:10.1089/cpb.2007. 9941

Valkenburg, P. S. (2005). Adolescents' identity experiments on the Internet. New Media \& Society, 7(3), 383-402.

Van Meter, R. A. (2015). “Of 'Likes' and 'Pins': The Effects of Consumers' Attachment to Social Media," . Journal of Interactive Marketing, 70-88.

Wei, M. R. (2005). Adult attachment, social self-efficacy, self-disclosure, loneliness, and subsequent depression for freshman college students: A longitudinal study . Journal of Counseling Psychology, 52(4), 602-614. 